\title{
A RETROSPECTIVE REVIEW OF CYTOGENETIC STUDIES ON METHYL ISOCYANATE WITH SPECIAL REFERENCE TO THE BHOPAL GAS TRAGEDY: IS THE NEXT GENERATION ALSO AT RISK?
}

\author{
RAVINDRA M. SAMARTH ${ }^{1}$, PUNEET GANDHI ${ }^{1}$, and KEWAL K. MAUDAR ${ }^{2}$
}

${ }^{1}$ Bhopal Memorial Hospital \& Research Centre, Bhopal, India

Department of Research in Medical Biotechnology

${ }^{2}$ Bhopal Memorial Hospital \& Research Centre, Bhopal, India

Department of GI Surgery

\begin{abstract}
The world's worst industrial disaster, at Union Carbide, Bhopal, India, took place on 2-3 December 1984, leading to the leakage of poisonous methyl-isocyanate into the environment, causing thousands of deaths, pregnancy loss and for some, incapacitation for life. More than a quarter of a century later, the Indian Council of Medical Research undertook to redefine the abysmal consequences of the toxic gas exposure on the exposed population. This invigorated the interest of scientific community in the evaluation of the long-term effects, with reference to cytogenetic parameters. The thrust area was identified in terms of genetic disorders, low birth weight, developmental/growth disorders and congenital malformations. Also the impact on epigenetic factors, which may have contributed to variations in the functional expression of genes, was not negated, stimulating intense scientific research on in utero exposure and the progeny of the exposed population. To accomplish this mammoth task, molecular cytogenetic investigations must be undertaken in conjunction with conventional cytogenetics, using techniques such as FISH, Immuno-FISH, SKY and SNP analysis, to build up a cytogenetic database of the surviving population.
\end{abstract}

Key words:

Bhopal gas tragedy, Methyl isocyanate (MIC), Cytogenetic studies, Molecular cytogenetic tools, Cytogenetic database

\section{INTRODUCTION}

During the midnight of 2nd December and dawn of 3rd December 1984, Bhopal was witness to the worst industrial disaster that occurred in history due to an explosion at the Union Carbide India pesticide plant, releasing more than 40 tones of methyl isocyanate (MIC) and its reaction products over the city [1]. The estimated mortality of this accident was believed to be between 2500 and 5000 people, with up to 200000 injured [2-5]. The main component of the toxic release, MIC, caused havoc not only within human life but also within the flora and fauna. The immediate effects of MIC on plants in the vicinity included defoliation, burnt patches and the drying of most aerial parts. Maximum damage was observed in succulent and xerophytic plants in which stomata usually remain open during the night. Newly-formed leaves suffered from chlorosis, necrosis or white patches appearing in mosaic patterns [6]. The same group also documented that aberrations in root

Received: July 30, 2012. Accepted: April 25, 2013.

Corresponding author: P. Gandhi, Department of Research in Medical Biotechnology, Bhopal Memorial Hospital \& Research Centre, Bhopal, India (e-mail: puneetgandhi67@yahoo.com). 
cells of Solanum surattense varied depending on the exposure to the gas [7]. However, in some plants such as Artocarpus integrifolia, Casuarina equisetifolia, Ficus bengalensis and Mangifera indica [8], striking findings of resistance to MIC were documented.

Immediately after the disaster, the Indian Council of Medical Research (ICMR) took up the task of monitoring the health effects of the disaster. On the basis of mortality figures, the ICMR estimated that over 520000 exposed persons had toxic adducts circulating in their bloodstream, which resulted in various degrees of damage to almost all the organ systems [9]. The ICMR published the findings of 24 research studies involving over 80000 survivors in the form of 3 reports available at http://www. icmr.nic.in [10]. However, the social stratification and the weather conditions at the accident site created a distinct division of the population into individuals mildly, moderately or severely exposed to the toxins, and exhibiting an equally explicit response. Detailed studies on various disorders including neuromuscular dysfunction of muscle and brain cells in cell lines, as well as in vivo studies on animals and the exposed individuals demonstrate the wide spectrum of toxic effects of MIC [11-15]. However, a significant number of published studies evaluating the toxicity of MIC are largely restricted to histopathological findings, especially of lungs and eyes, with small cross sectional studies delineating symptomatology and clinical morbidity in the MIC exposed survivors. As time passed, health status evaluation and rehabilitation of gas victims declined [9].

Clinical studies established that the survivors experienced a higher incidence of health problems including febrile illnesses and respiratory, neurological, psychiatric and ophthalmic symptoms [16,17]. An important study was conducted in 1990 to establish a genetic link between cancer patterns among victims of the gas tragedy with MIC exposure [18]. The population-based cancer register of the ICMR revealed higher incidence rates (crude and age-adjusted) of gallbladder carcinoma (GBC) in the surviving population of the Bhopal gas tragedy $[19,20]$. A hospital-based registration study of 1261 cancer sufferers who had been exposed to MIC and their offspring, conducted by Senthilkumar et al. [21], reported a gradual increase of cancers in different locations, along with some new cancer cases previously not reported in their population.

It must be noted that although a lot of scientific work has been published which summarize the health effects of MIC, some limitations of these studies have been highlighted. Many commentaries strongly emphasize the need for continued vigilance with regard to the long term adverse effects of MIC [22]. However, a limited number of reports is available on the conventional and molecular cytogenetic profiles of the individuals exposed to MIC, with reference to the genotoxic effects [23-27]. While these reports document the substantial linkage of MIC exposure to somatic mutagenesis, several shortcomings exist regarding their methodological approach. Hence, international groups advocated investigations on the toxicogenomic effects of MIC using cutting edge technologies [28-31]. The importance of experimental studies cannot be undermined, as alteration(s) at genomic and/or epigenetic level can have long-term health consequences that may range from immuno-compromised states to accelerated ageing, carcinogenesis, and more importantly, vertical transmission of genetic aberrations.

Recently, the ICMR has proposed incorporating any existing information into its MIC reports and seeking to decipher any persistent and subtle genotoxic effects of MIC in well-designed genome studies that might enhance the understanding of the extent and gravity of its long term effects [32]. Therefore, molecular cytogenetic investigations in conjunction with conventional cytogenetics, using the available cutting edge techniques such as FISH, Immuno-FISH, SKY and SNP analysis must be performed to build up a cytogenetic database of the surviving population. 


\section{METHYL ISOCYANATE AND CYTOGENETIC DAMAGE}

Isocyanates $(\mathrm{N}=\mathrm{C}=\mathrm{O})$ are low molecular weight organic, aromatic and aliphatic compounds, consisting of two double bonds, with strong chemical reactivity. Methyl isocyanate (MIC), toluene di-isocyanate (TDI), diphenyl methane di-isocyanate (MDI), hexamethylene di-isocyanate (HDI) and naphthalene di-isocyanate (NDI) are the most commonly used isocyanates for industrial purposes [33,34]. $\mathrm{MIC}(\mathrm{CH} 3 \mathrm{~N}=\mathrm{C}=\mathrm{O})$ is an intermediate chemical in the production of carbamate pesticides such as carbaryl, sevin, aldicarb, methomyl and carbofuran [35-37]. OEHHA (2001) guidelines have indexed MIC as a hazardous substance that during exposure targets the respiratory and reproductive systems [38].

Genetic information, encoded chemically in DNA, is maintained, replicated and transmitted to successive generations with high fidelity. Damage to DNA can occur through normal biological processes or as a result of interaction of DNA, either directly or indirectly, with chemical, physical or certain biological agents [39]. Genetic damage at the chromosomal level entails an alteration in either chromosome number or chromosome structure, and such alterations are measured in terms of chromosomal aberrations, micronucleus frequency and sister-chromatid exchanges. Hence, MIC, a well-known toxic industrial chemical found within the vicinity of a densely-populated area at UCIL, Bhopal, proved to be a potent disrupting agent of this biomolecule of life.

Cytogenetic biomonitoring of a population is an appropriate means of estimating the genetic risk from integrated exposure to complex mixtures of chemicals. Although a number of biomarkers are available to assess transient and permanent genotoxic responses, biomonitoring studies on human populations should essentially focus on more definitive cytogenetic end-points. New developments in the post-genomics era have provided tools for the assessment of environmental and occupational exposure to toxic substances. Identification and validation of various molecular cytogenetic biomarkers which confirm defined toxicogenomic effects and gene susceptibilities through polymorphism studies can substantiate our understanding of human occupational diseases.

\section{Cytogenetic studies in cell lines and small animals with reference to MIC}

The genotoxic potential of MIC in cultured cells after in vitro exposure to MIC has been evaluated in several studies (Table 1). Conner et al. [40] assessed sister chromatid exchange (SCE) levels and cell cycle kinetics in various murine tissues following MIC exposure, and discovered that despite its apparent cellular toxicity, MIC was not genotoxic as measured by SCE analysis. However, MIC was found to induce SCEs and chromosomal aberrations in CHO cells [41]. Shelby et al. [42] report that methyl isocyanate has the capacity to affect chromosome structure but not to induce gene mutations. In cultured peripheral blood lymphocytes, MIC was found to have a stimulatory effect on cell cycling rates, as measured by the replicative index, and it caused a significant reduction in mononuclear leucocyte counts and mitotic indices [43]. Meshram and Rao [44] report that MIC was mutagenic in its native form, or as its unknown metabolites, unlike its hydrolysis products [45]. Tamura et al. [46] demonstrated that the modification of M13mp9 RF DNA and SOS-dependent mutations in the beta-galactosidase locus in E. coli were MIC-dose dependent.

\section{Cytogenetic studies in rodents and human lymphocytes} with reference to MIC

Methyl isocyanate (MIC) has been assayed in a number of in vivo genetic toxicity tests to determine its ability to interact with DNA and to induce genetic damage (Table 2). Ennever and Rosenkranz [47] evaluated the genotoxic carcinogenicity of MIC and predict that it has significant potential for inducing cancer in rodents. Many groups of 
Table 1. Summarized investigations on MIC induced damage in cell lines and small animals

\begin{tabular}{llc}
\hline \multicolumn{1}{c}{ In vitro studies } & \multicolumn{1}{c}{ Cytogenetic and molecular parameters studied } & References \\
\hline $\begin{array}{l}\text { Evaluation of } \\
\text { genotoxic potential } \\
\text { of MIC in cultured }\end{array}$ & Sister chromatid exchanges (SCEs) and chromosomal aberrations (CA) in Chinese hamster & {$[42]$} \\
cells after in vitro & Perlls, mouse lymphoma cells and cultured mammalian cells & \\
exposure & Mononuclear leucocyte counts and mitotic indices & {$[40]$} \\
& MIC was assayed both in the presence and absence of Aroclor-1254-induced S9, using 5 tester & {$[44]$} \\
& strains of Salmonella typhimurium, TA97a, TA98, TA100, TA102 and TA104 & {$[43]$} \\
& Ames Salmonella/microsome mutagenicity test & {$[46]$} \\
\hline
\end{tabular}

Table 2. Summarized investigations on in vivo cytogenetic studies in plants, animals and humans exposed to MIC

\begin{tabular}{|c|c|c|}
\hline $\begin{array}{l}\text { In vivo } \\
\text { cytogenetic study }\end{array}$ & $\begin{array}{c}\text { Cytogenetic } \\
\text { parameters studied }\end{array}$ & References \\
\hline \multirow[t]{3}{*}{$\begin{array}{l}\text { Genotoxic potential } \\
\text { of MIC in exposed } \\
\text { plants }\end{array}$} & $\begin{array}{l}\text { Chromosomal abnormalities at highly significant levels in cultivated plants such as Solanum } \\
\text { melongena, Lycopersicon esculentum, Raphanus sativus, Brassica campestris and Lagenaria } \\
\text { vulgaris, and wild plants Solanum surattense, Datura alba and Argemone mexicana from affected } \\
\text { areas }\end{array}$ & [6] \\
\hline & $\begin{array}{l}\text { Chromosome aberrations in root cells, and growth retardation and chlorophyll mutation of seedlings, } \\
\text { the frequencies of which varied from one locality to another in seeds of Solanum surattense Burm }\end{array}$ & [7] \\
\hline & $\begin{array}{l}\text { Striking findings of resistance were documented in plants like Artocarpus integrifolia, Casuarina } \\
\text { equisetifolia, Ficus bengalensis and Mangifera indica }\end{array}$ & {$[8]$} \\
\hline \multirow{6}{*}{$\begin{array}{l}\text { Genotoxic potential } \\
\text { of MIC in exposed } \\
\text { animal subjects }\end{array}$} & MIC has a significant potential for inducing cancer in rodents & [47] \\
\hline & Sister chromatid exchanges (SCEs) and cell cycle kinetics in murine tissues & {$[40]$} \\
\hline & $\begin{array}{l}\text { Chromosomal aberrations and sister chromatid exchanges in bone marrow metaphase cells, } \\
\text { induction of micronuclei in polychromatic erythrocytes and the inhibition of bone marrow } \\
\text { cellular proliferation and erythropoiesis in mice }\end{array}$ & [48] \\
\hline & $\begin{array}{l}\text { In vivo micronucleus test, chromosomal aberrations, sister chromatid exchanges in bone marrow } \\
\text { cells of rodent somatic cells }\end{array}$ & [49] \\
\hline & In vivo micronucleus test and chromosomal analysis of bone marrow cells in mice & {$[50]$} \\
\hline & Mutagenic and cytotoxic effects in mouse micronucleus test & [51] \\
\hline \multirow{6}{*}{$\begin{array}{l}\text { Genotoxic potential } \\
\text { of MIC in exposed } \\
\text { human subjects }\end{array}$} & $\begin{array}{l}\text { Increased sister chromatid exchanges and chromosomal breaks have been reported in exposed } \\
\text { persons }\end{array}$ & {$[12,23-25]$} \\
\hline & Illustrated chromosomal profile of 154 persons studied during 1986-1988 & [26] \\
\hline & $\begin{array}{l}\text { Chromosomal abnormalities even } 1114 \text { days after exposure to the gas is suggestive of residual } \\
\text { effect on T-cell precursors and possibility of higher susceptibility to chromosome damage of } \\
\text { persons exposed to MIC }\end{array}$ & [27] \\
\hline & Established a genetic link of cancer patterns among victims of gas tragedy with MIC exposure & {$[18]$} \\
\hline & High pregnancy loss, increased first 5 -year mortality and delayed development of male progeny & {$[57]$} \\
\hline & The mean percentage of acrocentric associations in exposed population was significantly higher & {$[52,53]$} \\
\hline
\end{tabular}


workers have demonstrated that exposure to MIC by inhalation results in bone marrow damage, indicating that MIC or its reactive metabolites possess systemic genotoxic/cytotoxic activity [48-50]. MIC exposure was found to lead to inhibition of bone marrow cell proliferation by evaluation of the mutagenic and cytotoxic effects of MIC with a mouse micronucleus test [51].

Increased sister chromatid exchanges and chromosomal breaks have also been reported in exposed persons [12,2325]. A separate study illustrates the chromosomal profile of 154 persons studied over the years 1986-1988. The exposed subjects developed at least two categories of chromosomal aberrations, including a high number of Robertsonian translocations, most of which were in acrocentric chromosomes 13 and 21 [26]. Another investigation on 83 individuals directly exposed to MIC recorded chromosome breaks, gaps, dicentrics, rings, triradial and quadriradial configurations which were found to occur in statistically higher frequencies as compared to the non exposed group [27]. "The persistence of chromosomal abnormalities in the form of replicating minutes and exchange configurations, even 1114 days after exposure to the gas, indicates that MIC has a residual effect on T-cell precursors, and raises the possibility of persons exposed to MIC having greater susceptibility to chromosome damage" [27]. The presence of significantly more common structural aberrations in the MIC exposed population has been corroborated by Malla et al. [52,53], suggesting that the population is more vulnerable to genetic disorders and cancer.

\section{In utero studies in humans with reference to MIC}

As the impact of toxic exposure on epigenetic factors contributing to variation in the functional expression of genes has not fallen, a greater emphasis has been placed on researching the in utero exposure and progeny of the exposed population. Environmental signals during early life may lead to adverse long term effects independent of the obvious effects on fetal growth. Experimental data in rodents and recent observations in humans suggest that the epigenetic changes in the regulatory and growth-related genes play a significant role in foetal programming [54], whereby adverse long term effects reflect a mismatch between early (foetal and neonatal) and environmental conditions (Table 3).

Kapoor [55] documented, through a 5 year biodemographic study, that the fetal loss rate among the women affected by MIC gas was abnormally high $(26.3 \%)$ as compared to a control group (7.8\%). It has been suggested that MIC exposure in utero in the first trimester of pregnancy may induce a persistently hyper-responsive state of the immune system [56]. The non-targeted effects of toxic exposure such as bystander responses, genomic instability, gene induction, adaptive responses and low hypersensitivity may also be mirrored as trans-generational health effects. Sarangi et al. [57] report that exposure of pregnant

Table 3. Summarized investigations on in utero studies in humans exposed to MIC

\begin{tabular}{llc}
\hline \multicolumn{1}{c}{ In utero studies } & \multicolumn{1}{c}{ Parameters studied } & References \\
\hline $\begin{array}{l}\text { In utero exposed human } \\
\text { subjects }\end{array}$ & $\begin{array}{l}\text { The fetal loss rate among the gas-affected women was abnormally high (26.3\%) } \\
\text { compared to that of women in the control area (7.8\%) }\end{array}$ & {$[55]$} \\
& MIC exposure in utero in the first trimester of pregnancy has caused a persistently & {$[56]$} \\
& hyper-responsive state of the immune system & \\
& Stunted growth in males until puberty, followed by a period of accelerated growth. Results also & {$[57]$} \\
& suggest a post-puberty effect on head circumference of females exposed to gases in utero & \\
& $\begin{array}{l}\text { A high incidence spontaneous abortions and still-births in gas- exposed pregnant women } \\
\text { and significantly higher perinatal and neonatal mortalities in the affected areas were reported }\end{array}$ & {$[58]$} \\
\hline
\end{tabular}


women to toxic gases in 1984 resulted in high pregnancy loss, increased 5-year mortality of the offspring of the exposed parents and delayed development of male progeny. They report that male, but not female, offspring exposed to gases in utero or born to exposed parents, were stunted in growth until puberty, which was followed by a period of accelerated growth. Their study results also suggest a postpuberty effect on head circumference of females exposed to gases in utero. There was a high incidence of spontaneous abortions and still-births in pregnant women exposed to the gas and significantly higher perinatal and neonatal mortalities in the affected areas [58]. Consequently, screening of MIC-induced trans-generational alterations in the germline genome of $\mathrm{F} 0, \mathrm{~F} 1$ and $\mathrm{F} 2$ generations of Bhopal gas victims may address the less understood environmental influence of heritable or familial components of susceptibility to infectious and chronic non-communicable diseases [59].

\section{Molecular studies with reference to MIC}

There has been little progress over the last few years regarding understanding the genotoxic mechanisms of MIC within human cells in vitro (Table 4). It has been demonstrated that methyl isocyanate might promote cell cycle arrest and apoptosis in cultured mammalian cells suggestive of causing genetic alterations by negative regulation of the DNA damage response pathway [60]. The toxic response of cultured human colon epithelial-FHC cells to methyl isocyanate has been previously investigated with regard to genomic instability in colonocytes [61]. According to Raghuram et al. [62], ovarian epithelial cells manifest a persistent DNA damage response upon treatment with methyl isocyanate. Another study performed in order to determine the pathophysiological implications of isocyanate exposure on the male germ line GC-1 spg cell line indicated induced genomic instability with evidence of dysregulation of cell cycle progression [63]. Bose and Bathri [64] used ISSR-PCR to examine the effects of MIC exposure among a cross-section of current survivors suffering from COPD for microsatellite instability. Their study showed a weak association between microsatellite instability and age, exposure distance from site and smoking status, while regression analysis provided supporting evidence.

\section{THE NEXT GENERATION}

Children in developing nations are at a higher risk of dual exposure to infectious diseases and chemical hazards. Their burden of exposure-based disease is much greater than that of adults due to compounding factors such as immature metabolic pathways, easily disrupted growth and development processes and longer lifespan, which provide more time for harboring chronic diseases triggered

Table 4. Summarized investigations on molecular studies with reference to MIC

\begin{tabular}{|c|c|c|}
\hline Molecular studies & Parameters studied & References \\
\hline \multirow[t]{5}{*}{$\begin{array}{l}\text { Molecular studies with } \\
\text { reference to MIC }\end{array}$} & $\begin{array}{l}\text { Assessed the genotoxic potential of methyl isocyanate in cultured mammalian cells } \\
\text { in three different normal cell lines MM55.K, B/CMBA.Ov, and NIH/3T3 }\end{array}$ & {$[60]$} \\
\hline & $\begin{array}{l}\text { Chromosomal anomalies, expression of pericentrin protein, ISSR PCR-microsatellite } \\
\text { instability in colonocytes }\end{array}$ & {$[61]$} \\
\hline & $\begin{array}{l}\text { Ovarian epithelial cells manifested DNA damage response, GADD45, p21, p16 } \\
\text { (INK4A) and pRb proteins }\end{array}$ & {$[62]$} \\
\hline & $\begin{array}{l}\text { Chromosomal aberrations, telomere anomaly, aneuploidy and microsatellite repeat in } \\
\text { cultured mouse spermatogonial cell line }\end{array}$ & {$[63]$} \\
\hline & $\begin{array}{l}\text { The effects of exposures among a cross-section of current residents suffering from } \\
\text { COPD by ISSR PCR-microsatellite instability }\end{array}$ & {$[64]$} \\
\hline
\end{tabular}


by early exposure. Unfortunately, the Bhopal Gas tragedy appears to be no exception, rather a harbinger of conditions yet to develop [65-67].

Studies by Ghosh et al. [27] and Dikshit and Kanhere [18] indicate probable long term effects of MIC and hint at the inevitability of focusing on cohort-based investigations in order to understand the molecular mechanisms of chromosomal damage, their extent in the population and chances of enhanced susceptibility of DNA damage due to a genetic predisposition in the following generation, creating a high risk group which may be carrying a genetic load [68]. In the assessment of the effects of exposure to toxic chemicals such as MIC; the age, sex of the subject, physiological and nutritional statuses, as well as other confounding factors, have to be taken into account $[69,70]$. There is a compelling need for detailed investigations into the health implications of children's exposure to environmental toxins, with special reference to the high prevalence conditions, such as childhood cancer, asthma, endocrine and sexual disorders, and neurobehavioral toxicants [71]. Anthropometric studies in adolescents carried out by Ranjan et al. [72] identified selective growth retardation in boys either exposed to the toxic MIC gas as toddlers or born to the exposed patients but not in girls. Based on survey studies conducted by Irani and Mahashur [74] on children exposed to MIC and complaining of persistent respiratory, gastrointestinal and eye problems, Woolf and Sandel [73] state that there are still many unanswered questions concerning the long-term residual effects of MIC exposure on the health of children, which require specific and cohort-based cytogenetic studies and their appropriate interpretation.

\section{TOOLS AVAILABLE}

Cytogenetic analysis of peripheral blood lymphocytes (PBLs) has been accepted as a suitable assay for the biological monitoring of genetic damage induced by excessive exposure to clastogenic agents in the workplace [75-77].
Also, the evaluation of micronuclei in PBLs is a valuable cytogenetic biomarker in human populations occupationally exposed to genotoxic compounds [78,79]. A high frequency of chromosomal aberrations (CAs) and micronuclei (MN) in PBLs is a predictor of an increased risk of cancer [80-82]. Preliminary results of genomic studies suggest that certain genotypes of drug-metabolizing enzyme genes, such as GSTM1 null genotype, NAT1 slowacetylator genotype, and GSTP1 slow-activity genotype, may confer an increased risk of isocyanate-induced asthma, and hence, can be used for risk assessment [83]. SKY has been applied to various tumor groups including hematological malignancies, sarcomas, carcinomas and brain tumors, with the intent to identify specific chromosomal abnormalities that may provide an insight into the genes involved in disease process, as well as identify recurrent cytogenetic markers for clinical diagnosis and prognostic assessment [84]. Researchers have shown a slight correlation between single nucleotide polymorphisms (SNPs) and environmentally responsive genes [85], and another between the airway inflammatory proteins, glutathioneS-transferase P1 and tumour necrosis factor, interacting with geocoded ambient levels of nitrogen oxides [86]. Variants of chromosome 17q21 were strongly associated with the risk of early-onset asthma in a replication study of SNPs on exposure to environmental tobacco smoke [87]. Therefore, molecular cytogenetic studies of allelic variability and resequencing data can play a pivotal role in the evaluation of a subjects' adaptation to environmental xenobiotics [88-90]. However, there is a need to use cutting-edge molecular technologies which can provide data to understand the genesis of environment-related disorders, and thus identify the causal links between exposure and a specific human disease [91]. Chromosomal abnormalities represent Nature's guide to the molecular basis of many unexplained disease conditions. More than fifty years have passed since the discovery of the number of human chromosomes in 1956. New techniques have developed since then, ranging from 


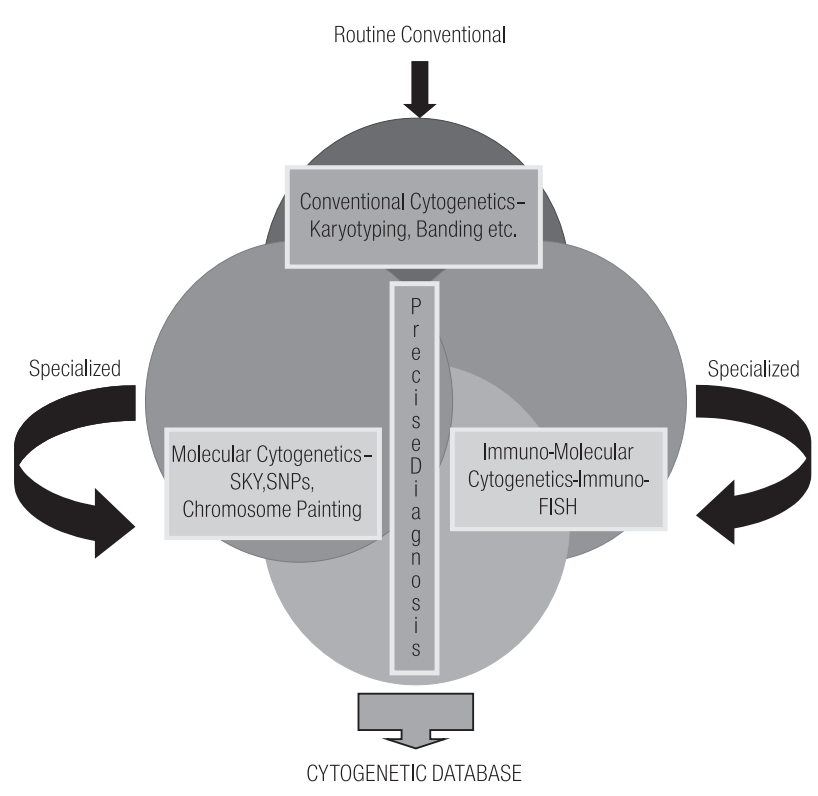

Fig. 1. Schematic representation of various tools available for cytogenetic studies to create a cytogenetic database

the conventional banding techniques to the currently used molecular array comparative genomic hybridization. With a combination of these conventional and molecular techniques, cytogenetics has become an indispensable tool used in the diagnosis of various genetic disorders, simultaneously paving the way for possible treatment and management [92]. This can be achieved by an amalgamation of conventional and advanced molecular tools that capitalize on the power of available cutting edge techniques to build up a cytogenetic database (Figure 1) of the surviving population in order to aid diagnosis of genetic disorders and their possible treatment and management. To summarize, it is necessary to undertake studies to examine the molecular toxicological effects of gaseous toxins, including those mimicking MIC, using whole genome scanning approaches.

\section{FUTURE PERSPECTIVES}

Chromosomal aberrations induced by environmental exposure represent a proportion of genetic disorders often being transmitted as a germline mutations. A higher incidence of chromosomal abnormalities at the prenatal or postnatal stages in human beings is relatively common in a population with any kind of genotoxic exposure. The MIC catastrophe has not been the last such industrial disaster. There have been other accidents of various magnitude like leakage of chlorine gas from the water filtration plant of BHEL-Bhopal, India [93] and radiation leakage from Fukushima Nuclear plant in Japan [94], with slightly different toxins involved but very similar after-effects.

The effect(s) of such environmental toxins in children are mediated, partly, by their genetic make-up and partly by the existence of genetic variants and polymorphisms of certain genes which confer relative age-related vulnerability or resistance to molecular perturbations and cellular dysfunctions which may manifest downstream as phenotypic variation(s) and clinical toxicity. Also there may be environmental influences on epigenetic factors that contribute to variations in the functional expression of genes. A study of transgenerational epigenetic signatures, especially in the offspring of Bhopal gas tragedy victims is an area seeking scientific attention. Although conventional cytogenetics using banded chromosomal analysis remains a simple and popular technique to get an overview of the human genome, a combination of routine banded karyotype analysis with Immuno-FISH and other various molecular techniques can achieve a more precise diagnosis of various syndromes in children [95]. Microarray-based formats using large insert genomic clones, cDNAs or oligonucleotides can replace metaphase chromosomes as DNA targets, providing higher resolution and the ability to directly map the copy number changes to the genome sequence [92].

Both conventional and molecular technique-based investigations, must now be focused on understanding the molecular mechanisms of chromosomal damage; delineating a high risk population and its susceptibility to DNA damage and genetically-predisposed cancers, with the 
identification of individuals hypersensitive to selected genotoxins. This research can prove to be beneficial in designing clinical management strategies to overcome or minimize the disastrous effects of similar exposure in the future.

\section{CONCLUSION}

Intense research on in utero exposure and progeny of the exposed population is being augmented. Molecular cytogenetic studies using techniques like FISH, ImmunoFISH, SKY and SNP analysis, are warranted to build up a cytogenetic database of the surviving cohort to substantiate the sparse data available concerning threshold values of various cytogenetic markers so as to identify and define susceptibility indicators, if any.

\section{ACKNOWLEDGEMENT}

Authors are grateful to Bhopal Memorial Hospital \& Research Centre for IRB sanctioned Research Project on Cytogenetic Workstation (IRB/11/Research/2010). The authors have made a careful attempt to cite all available reports on cytogenetic studies pertaining to MIC exposure, however, exclusions, if any, are regretted.

\section{REFERENCES}

1. Broughton E. The Bhopal disaster and its aftermath: A review. Environ Health 2005;4:6.

2. Mehta PS, Mehta AS, Mehta SJ, Makhijani AB. Bhopal tragedy's health effects. A review of methyl isocyanate toxicity. JAMA 1990;264:2781-7.

3. Dhara VR, Dhara R, Acquilla SD, Cullinan P. Personal exposure and long-term health effects in survivors of the Union Carbide disaster at Bhopal. Environ Health Perspect 2002;110:487-500.

4. Sharma DC. Bhopal: 20 years on. Lancet 2005;365:111-2.
5. Mishra PK, Samarth RM, Pathak N, Jain SK, Banerjee S, Maudar KK. Bhopal gas tragedy: Review of clinical and experimental findings after 25 years. Int J Occup Med Environ Health 2009;22:1-10.

6. Kumar G, Tripathi DS, Roy SK. Cytological effects on plants by an accidental leakage of methylisocyanate (MIC) gas. Environ Exp Bot 1989;29:261-71.

7. Kumar G, Sahi AN, Roy SK. Induction of chromosome aberrations and chlorophyll mutations in plants by methylisocyanate (MIC) gas. Cell Mol Life Sci 1990;46:1072-5.

8. Garg A, Pandey H, Chakraverty N, Bose P, Punde RP, Samarth RM, et al. Section F: Medicinal Bonsai. In: Gandhi P, Maudar KK, editors. Combating the cytotoxic insult: A pharmacognostic approach [cited 2012 May 15]. Vol. 1. Bhopal (India): A BMHRC publication; 2010. Available from URL: http://www.bmhrc.org/Bhopal\%20Memorial/ PDF/COVER\%20PAGE.pdf.

9. Dinham B, Sarangi S. The Bhopal gas tragedy 1984 to? The evasion of corporate responsibility. Environ Urban 2002;14: 89-99.

10. Synopsis of technical report on population based long term clinical studies [cited 2012 June 6]. Available from URL: http:// www.icmr.nic.in/final/synopsis_tech_rep_clinical.pdf.

11. Government of India. Report on the factors related to Bhopal toxic gas leakage. New Delhi: Government; 1985.

12. National Toxicology Program. The toxicity of methyl isocyanate. Environ Health Perspect 1986;72:1-200.

13. Bhopal gas tragedy. Bhopal gas disaster: clinical \& experimental studies. Ind J Exp Biol 1988;26:149-204.

14. Anderson D, Goyle S, Phillips BJ, Tee A, Beech L, Butler WH. Effects of methyl isocyanate on rat muscle cells in culture. Br J Ind Med 1988;45:269-74.

15. Anderson D, Goyle S, Phillips BJ, Tee A, Beech L, Butler WH. Effects of methyl isocyanate on rat brain cells in culture. Br J Ind Med 1990;47:596-601.

16. Cullinan P, Acquilla SD, Dhara VR. Long term morbidity in survivors of the 1984 Bhopal gas leak. Natl Med J India 1996;9:5-10. 
17. Vijayan VK, Sankaran K. Relationship between lung inflammation, changes in lung function and severity of exposure in victims of the Bhopal tragedy. Eur Respir J 1996;9:1977-82.

18. Dikshit RP, Kanhere S. Cancer patterns of lung, oropharynx and oral cavity cancer in relation to gas exposure at Bhopal. Cancer Causes Control 1999;10:627-36.

19. Sriramachari S. The Bhopal gas tragedy: An environmental disaster. Curr Sci 2004;86:905-20.

20. Mishra PK, Jatawa SK, Raghuram GV, Pathak N, Jain A, Tiwari A, et al. Correlation of aberrant expression of p53, Rad50, and cyclin-E proteins with microsatellite instability in gallbladder adenocarcinomas. Genet Mol Res 2009;8:1202-10.

21. Senthilkumar CS, Malla TM, Sah NK, Ganesh N. Cancer morbidity among methyl isocyanate exposed long-term survivors and their offspring: A hospital-based five year descriptive study (2006-2011) and future directions to predict cancer risk in the affected population. Asian Pac J Cancer Prev 2011;12:3443-52.

22. Shrivastava R. Bhopal gas disaster: Review on health effects of methyl isocyanate. Res J Environ Sci 2011;5(2):150-6.

23. Goswami HK, Guron C, Jain N, Goswami I. Genetic assessment of Union Carbide gas tragedy in Bhopal. I. Effects on somatic chromosomes and haemoglobin. Bionature 1984;4:88-90.

24. Goswami HK. Cytogenetic effects of methyl isocyanate exposure in Bhopal. Hum Genet 1986;74:81-4.

25. Talukder G, Sharma A. The Bhopal accident: its after effects. In: Majumdar SK, Miller EW, Schmalz RF, editors. Management of hazardous materials and wastes. Easton, PA (USA): Pennsylvania Academy of Science Publication; 1989. p. 409-17.

26. Goswami HK, Chandorkar M, Bhattacharya K, Vaidyanath G, Parmar D, Sengupta S, et al. Search for chromosomal variations among gas-exposed persons in Bhopal. Hum Genet 1990;84:172-6.

27. Ghosh BB, Sengupta S, Roy A, Maity S, Ghosh S, Talukder $\mathrm{G}$, et al. Cytogenetic studies in human populations exposed to gas leak at Bhopal, India. Environ Health Perspect 1990;86:323-6.
28. Crabb C. Revisiting the Bhopal gas tragedy. Science 2004; 306:1670-1.

29. Dhara VR, Dhara R. The union carbide disaster in Bhopal: A review of health effects. Arch Environ Health 2002;57: 391-404.

30. Gupta JP. Bhopal gas tragedy and its effects on process safety. International Conference on the 20th anniversary of Bhopal gas tragedy; 2004 Dec 1-3; IIT-Kanpur, India. Conference Report. J Hazard Mater 2005;125:272-4.

31. Sriramachari S. Bhopal gas tragedy: Scientific challenges and lessons for future. J Loss Prev Proc Ind 2005;18:264-7.

32. Indian Council of Medical Research. Health effects of the toxic gas leak from the methyl isocyanate Plant in Bhopal [cited 2012 May 30]. Available from URL: http://www.icmr. nic.in/ncrp/Bhopal\%20Gas\%20Report.pdf.

33. Nakashima K, Takeshita T, Morimoto K. Review of the occupational exposure to isocyanates: Mechanisms of action. Environ Health Prev Med 2002;7:1-6.

34. Chemical Control Centre. Isocyanates. Laboratory safety bulletin [cited 2012 June 15]. Windsor: Chemical Control Centre, University of Windsor; 2008. Available from URL: http://www.uwinsor.ca/ccc.

35. Bucher JR. Methyl isocyanate: A review of health effects research since Bhopal. Fund Appl Toxicol 1987;9:367-79.

36. Agency for Toxic Substances and Disease Registry. Methyl isocyanate. Atlanta, GA (USA): Emergency Department Management. ATSDR. U.S. Department of Health and Human Services; 2002.

37. Department of Health and Senior Services. Hazardous substance fact sheet: Methyl isocyanate. RTK 1270. New Jersey: Department; 2002.

38. Office of Environmental Health Hazard Assessment. Methyl isocyanate. Chronic toxicity summary, determination of noncancer chronic reference exposure levels [cited 2012 May 30]. Sacramento, CA (California): EHHA; 2001. Available from URL: http://www.oehha.ca.gov.

39. Brusick D. Fundamentals of genetic toxicology. Principles of genetic toxicology. New York: Plenum Press; 1980. p. 11-44. 
40. Conner MK, Rubinson HF, Ferguson JS, Stock MF, Alarie Y. Evaluation of sister chromatid exchange and cytotoxicity in murine tissues in vivo and lymphocytes in vitro following methyl isocyanate exposure. Environ Health Perspect 1987;72:177-82.

41. Mason JM, Zeiger E, Haworth S, Ivett J, Valencia R. Genotoxicity studies of methyl isocyanate in Salmonella, Drosophila, and cultured Chinese hamster ovary cells. Environ Mutagen 1987;9:19-28.

42. Shelby MD, Allen JW, Caspary WJ, Haworth S, Ivett J, Kligerman A, et al. Results of in vitro and in vivo genetic toxicity tests on methyl isocyanate. Environ Health Perspect 1987;72:183-7.

43. Kligerman AD, Campbell JA, Erexson GL, Allen JW, Shelby MD. Sister chromatid exchange analysis in lung and peripheral blood lymphocytes of mice exposed to methyl isocyanate by inhalation. Environ Mutagen 1987;9:29-36.

44. Meshram GP, Rao KM. Mutagenicity of methyl isocyanate in the modified test conditions of Ames Salmonella/microsome liquid-preincubation procedure. Mutat Res 1988;204:123-9.

45. Meshram GP, Malini RP, Rao KM. Mutagenicity of $N, N$ '-dimethylurea and methylamine hydrochloride in the Ames Salmonella/microsome test: absence of mutagenic response. Mutat Res 1992;279:275-80.

46. Tamura N, Aoki K, Lee MS. Selective reactivities of isocyanates towards DNA bases and genotoxicity of methylcarbamoylation of DNA. Mutat Res 1992;283:97-106.

47. Ennever FK, Rosenkranz HS. Evaluating the potential for genotoxic carcinogenicity of methyl isocyanate. Toxicol Appl Pharmacol 1987;91:502-5.

48. Tice RR, Luke CA, Shelby MD. Methyl isocyanate: An evaluation of in vivo cytogenetic activity. Environ Mutagen 1987;9:37-58.

49. Tice RR. The cytogenetic evaluation of in vivo genotoxic and cytotoxic activity using rodent somatic cells. Cell Biol Toxicol 1988;4:475-86.

50. Kar RN, Khan KA, Sethi N. Genotoxicity studies on mice after short term inhalation exposure to methyl isocyanate. Cytobios 1989;59:167-76.
51. Meshram GP, Rao KM. Cytogenetic activity of methyl isocyanate in vivo in the mouse micronucleus test. Toxicol Lett 1988;42:65-71.

52. Malla TM, Sharma NC, Ganesh N. Frequency of acrocentric associations in Bhopal gas tragedy survivors. Int J Cell Mol Biol 2010;1:26-30.

53. Malla TM, Senthilkumar CS, Sharma NC, Ganesh N. Chromosome instability among Bhopal gas tragedy survivors. Am Eur J Toxicol Sci 2011;3:245-9.

54. Gicquel C, El-Osta A, Le Bouc Y. Epigenetic regulation and fetal programming. Best Pract Res Clin Endocrinol Metab 2008;22:1-16.

55. Kapoor R. Fetal loss and contraceptive acceptance among the Bhopal gas victims. Soc Biol 1991;38:242-8.

56. Mishra PK, Dabadghao S, Modi GK, Desikan P, Jain A, Mittra I, et al. In-utero exposure to methyl isocyanate in the Bhopal gas disaster: Evidence of persisting hyper-activation of immune system two decades later. Occup Environ Med 2009;66:279.

57. Sarangi S, Zaidi T, Pal RK, Katgara D, Gadag VG, Mulay S, et al. Effects of exposure of parents to toxic gases in Bhopal on the offspring. Am J Ind Med 2010;53:836-41.

58. Vijayan VK. Methyl isocyanate (MIC) exposure and its consequences on human health at Bhopal. Int J Environ Stud 2010;67:637-53.

59. Mishra PK. A pragmatic \& translational approach of human biomonitoring to methyl isocyanate exposure in Bhopal. Indian J Med Res 2012;135:479-84.

60. Mishra PK, Gorantla VR, Akhtar N, Tamrakar P, Jain SK, Maudar KK. Analysis of cellular response to isocyanate using $\mathrm{N}$-succinimidyl $\mathrm{N}$-methylcarbamate exposure in cultured mammalian cells. Environ Mol Mutagen 2009;50:328-36.

61. Mishra PK, Bhargava A, Raghuram GV, Jatawa SK, Akhtar N, Khan S, et al. Induction of genomic instability in cultured human colon epithelial cells following exposure to isocyanates. Cell Biol Int 2009;33:675-83.

62. Raghuram GV, Pathak N, Jain D, Panwar H, Pandey H, Jain SK, et al. Molecular mechanisms of isocyanate induced 
oncogenic transformation in ovarian epithelial cells. Reprod Toxicol 2010;30:377-86.

63. Raghuram GV, Pathak N, Jain D, Pandey H, Panwar H, Jain SK, et al. Molecular characterization of isocyanate-induced male germ-line genomic instability. J Environ Pathol Toxicol Oncol 2010;29:213-34.

64. Bose P, Bathri R. Association of microsatellite instability and chronic obstructive pulmonary disorder in isocyanate-exposed population of Bhopal. Ind J Human Genet 2012;18:172-6.

65. Suk WA, Ruchirawat KM, Balakrishnan K, Berger M, Carpenter D, Damstra T, et al. Environmental threats to children's health in South East Asia and the Western Pacific. Environ Health Perspect 2003;111(10):1340-7.

66. Pronczuk J, Surdu S. Children's environmental health in the twenty-first century. Ann NY Acad Sci 2008;1140:143-54.

67. Landrigan PJ, Miodovnik A. Children's health and the environment: An overview. Mt Sinai J Med 2011;78(1):1-10.

68. Sengupta LK, Sengupta S, Gandhi P, Goswami HK. Our chromosomal load. Bionature 1990;10:77-81.

69. Scott D, Roberts SA. Extrapolation from in vitro tests to human risk: Experience with sodium fluoride clastogenicity. Mutat Res 1987;189:47-58.

70. Sharma A. Environment and genetic polymorphism in Indian populations. Plenary lecture at the meeting of American Association for the Advancement of Science. Chicago: American Association for the Advancement of Science; 1987.

71. Landrigan PJ, Carlson JE, Bearer CF, Cranmer JS, Bullard RD, Etzel RA, et al. Children's health and the environment: A new agenda for prevention research. Environ Health Perspect 1998;106:787-94.

72. Ranjan N, Sarangi S, Padmanabhan VT, Holleran S, Ramakrishnan R, Varma DR. Methyl isocyanate exposure and growth patterns of adolescents in Bhopal. JAMA 2003;290:1856-7.

73. Woolf AD, Sandel M. Susceptibility of children to environmental xenobiotics. General, applied and systems toxicology. Boston, MA (USA): John Wiley \& Sons, Ltd.; 2009. DOI: 10.1002/9780470744307.gat104
74. Irani SF, Mahashur AA. A survey of Bhopal children affected by methyl isocyanate gas. J Postgrad Med 1986;32:195-8.

75. Buckton KE, Evans HJ. Methods for the analysis of human chromosome aberrations. Geneva: World Health Organization; 1973.

76. Kilian DJ, Picciano D. Cytogenetic surveillance of industrial populations. In: Hollander A, editor. Chemical mutagens. Principles and methods for their detection. Vol. 4. New York: Plenum; 1976.

77. Natrajan AT, Obe G. Screening of human populations for mutations induced by environmental pollutants: use of human lymphocyte system. Ecotoxicol Environ Saf 1980;4:468-81.

78. Albertini RJ, Anderson D, Douglas GR, Hagmer L, Hemminki K, Merlo F, et al. IPCS guidelines for the monitoring of genotoxic effects of carcinogens in humans. Mutat Res 2000;463:111-72.

79. Bolognesi C, Landini E, Perrone E, Roggieri P. Cytogenetic biomonitoring of a floriculturist population in Italy: Micronucleus analysis by fluorescence in situ hybridization (FISH) with an all-chromosome centromeric probe. Mutat Res 2004;557:109-17.

80. Bonassi S, Hagmer L, Stromberg U, Montagud AH, Tinnerberg H, Forni A, et al. Chromosomal aberrations in lymphocytes predict human cancers independently of exposure to carcinogens. Cancer Res 2000;60:1619-25.

81. Bonassi S, Ugolini D, Kirsch-Volders M, Strömberg U, Vermeulen R, Tucker JD. Human population studies with cytogenetic biomarkers: review of the literature and future prospectives. Environ Mol Mutagen 2005;45:258-70.

82. Rossner P, Boffetta P, Ceppi M, Bonassi S, Smerhovsky Z, Landa $\mathrm{K}$, et al. Chromosomal aberrations in lymphocytes of healthy subjects and risk of cancer. Environ Health Perspect 2005;113:517-20.

83. Vainio H, Rosenberg C, Hirvonen A, Norppa H. International workshop on biomarkers for isocyanates. Scand J Work Environ Health 1999;25:157-9.

84. Bayani JM, Squire JA. Applications of SKY in cancer cytogenetics. Cancer Invest 2002;20:373-86. 
85. Herbert MR, Russo JP, Yang S, Roohi J, Blaxill M, Kahler SG, et al. Autism and environmental genomics. Neurotoxicology 2006;27:671-84.

86. Melén E, Nyberg F, Lindgren CM, Berglind N, Zucchelli M, Nordling E, et al. Interactions between glutathione S-transferase P1, tumor necrosis factor, and traffic-related air pollution for development of childhood allergic disease. Environ Health Perspect 2008;116:1077-84.

87. Bouzigon E, Corda E, Aschard H, Dizier MH, Boland A, Bousquet J, et al. Effect of $17 q 21$ variants and smoking exposure in early-onset asthma. N Engl J Med 2008;359:1985-94.

88. Arking DE, Cutler DJ, Brune CW, Teslovich TM, West K, Ikeda $\mathrm{M}$, et al. A common genetic variant in the neurexin superfamily member CNTNAP2 increases familial risk of autism. Am J Hum Genet 2008;82:160-4.

89. Bakkaloglu B, Anlar B, Anlar FY, Oktem F, Pehlivantürk B, Unal F, et al. Atopic features in early childhood autism. Eur J Paediatr Neurol 2008;12:476-9.
90. Bakkaloglu B, O'Roak BJ, Louvi A, Gupta AR, Abelson JF, Morgan TM, et al. Molecular cytogenetic analysis and resequencing of contactin associated protein-like 2 in autism spectrum disorders. Am J Hum Genet 2008;82:165-73.

91. Angerer J, Ewers U, Wilhelm M. Human biomonitoring: State of the art. Int J Hyg Environ Health 2007;210:201-28.

92. Kannan TP, Alwi ZB. Cytogenetics: Past, present and future. Malays J Med Sci 2009;16:4-9.

93. The Economic Times. Chlorine gas leaks from BHEL plant in Bhopal; 3 hospitalised [cited 2012 June 30]. Available from URL: http://articles.economictimes.indiatimes.com/2011-08-23/ news/29918829_1_chlorine-gas-water-filtration-plant-bhel.

94. BBC News Asia-Pacific.Japan earthquake: Explosion at Fukushima nuclear plant. [cited 2012 May 15]. Available from URL: http://www.bbc.co.uk/news/world-asia-pacific-12720219.

95. Samarth RM, Gandhi P, Pandey H, Maudar KK. Mosaicism for trisomy 21 and ring (21) in a male born to normal parents: A case report. Gene 2012;511:109-12.

This work is available in Open Access model and licensed under a Creative Commons Attribution-NonCommercial 3.0 Poland License - http://creativecommons.org/ licenses/by-nc/3.0/pl/deed.en. 